\title{
Cloning, expression and characterization of a poly(3-hydroxybutyrate) depolymerase from Marinobacter sp. NK-1
}

\author{
Ken-ichi Kasuya ${ }^{\text {a,*, }}$, Tsutomu Takano ${ }^{\text {a }}$, Yoko Tezuka ${ }^{\text {a }}$, W.-C. Hsieh ${ }^{\text {a }}$, Hiroshi Mitomo ${ }^{\text {a }}$, \\ Yoshiharu Doi ${ }^{b}$ \\ a Material Science Laboratory, Department of Biological and Chemical Engineering, Faculty of Engineering, \\ Gunma University, 1-5-1 Tenjin, Kiryu-shi, Gunma 376-8515, Japan \\ ${ }^{\mathrm{b}}$ Polymer Chemistry Laboratory, The Institute of Physical and Chemical Research (RIKEN), \\ 2-1 Hirosawa, Wako-shi, Saitama 351-0198, Japan
}

Received 22 January 2003; received in revised form 11 July 2003; accepted 14 August 2003

\begin{abstract}
A DNA fragment carrying the gene encoding poly(3-hydroxybutyrate) $(\mathrm{P}(3 \mathrm{HB}))$ depolymerase was cloned from the genomic DNA of Marinobacter sp. DNA sequencing analysis revealed that the Marinobacter sp. $\mathrm{P}(3 \mathrm{HB})$ depolymerase gene is composed of 1734 bp and encodes 578 amino acids with a molecular mass of $61,757 \mathrm{Da}$. A sequence homology search showed that the deduced protein contains the signal peptide, catalytic domain (CD), cadherin-type linker domain (LD), and two substrate-binding domain (SBD). The fusion proteins of glutathione $S$-transferase (GST) with the CD showed the hydrolytic activity for denatured $\mathrm{P}(3 \mathrm{HB})(\mathrm{dP}(3 \mathrm{HB})), \mathrm{P}(3 \mathrm{HB}) \mathrm{emulsion}(\mathrm{eP}(3 \mathrm{HB}))$ and $p$-nitrophenylbutyrate. On the other hand, the fusion proteins lacking the SBD showed much lower hydrolytic activity for $\mathrm{dP}(3 \mathrm{HB})$ compared to the proteins containing both $\mathrm{CD}$ and SBD. In addition, binding tests revealed that the SBDs are specifically bound not to $\mathrm{eP}(3 \mathrm{HB})$ but $\mathrm{dP}(3 \mathrm{HB})$. These suggest that the SBDs play a crucial role in the enzymatic hydrolysis of $\mathrm{dP}(3 \mathrm{HB})$ that is a solid substrate. (C) 2003 Elsevier B.V. All rights reserved.
\end{abstract}

Keywords: Marinobacter; P(3HB) depolymerase; SBD; GST; Cadherin-type linker domain

\section{Introduction}

Poly(3-hydroxybutyrate) $(\mathrm{P}(3 \mathrm{HB}))$ is a kind of aliphatic polyester that is synthesized as a carbon reserve in the cell of various bacteria $[1,2]$. $\mathrm{P}(3 \mathrm{HB})$ exists as amorphous granules (native $\mathrm{P}(3 \mathrm{HB}) ; \mathrm{nP}(3 \mathrm{HB})$ ) in the cells, while it is transformed into a semi-crystalline state (denatured $\mathrm{P}(3 \mathrm{HB})$; $\mathrm{dP}(3 \mathrm{HB}))$ after being extracting from the cell [3]. $\mathrm{P}(3 \mathrm{HB})$ has also received much attention as a thermoplastic with biodegradable and biocompatible properties [4,5]. In various natural environments, $\mathrm{dP}(3 \mathrm{HB})$ is degraded into $3 \mathrm{HB}$ monomer and its oligomers by extracellular $\mathrm{P}(3 \mathrm{HB})$ depolymerases from $\mathrm{P}(3 \mathrm{HB})$-degrading microorganisms [5-10]. All of the cloned extracellular $\mathrm{P}(3 \mathrm{HB})$ depolymerases found so far have been composed of three functional domains: that is, catalytic domain (CD) to cut the

\footnotetext{
* Corresponding author. Tel.: +81-277-30-1481; fax: +81-277-30-1401.

E-mail address: kkasuya@bce.gunma-u.ac.jp (K.-i. Kasuya).
}

ester bond, a substrate binding domain (SBD) to attach the enzyme to the surface of the polyester, and a linker domain (LD), which exists between CD and SBD [9,11,12]. These functional domains cooperate to degrade $\mathrm{dP}(3 \mathrm{HB})$ with a highly organized crystalline region $[13,14]$. On the other hand, Jendrossek et al. [9,10] reported a new type of extracellular $\mathrm{P}(3 \mathrm{HB})$ depolymerase (PhaZ7) which does not degrade $\mathrm{dP}(3 \mathrm{HB})$ but amorphous $\mathrm{P}(3 \mathrm{HB})$, such as atactic $\mathrm{P}(3 \mathrm{HB})$, native or artificial granules of $\mathrm{P}(3 \mathrm{HB})$ [15]. In contrast to conventional extracellular $\mathrm{P}(3 \mathrm{HB})$ depolymerases, PhaZ7 did not have a domain structure and showed sequence homology with LipA and LipB of Bacillus subtilis lipase.

Previously, the $\mathrm{P}(3 \mathrm{HB})$-degrading bacterium Marinobacter $\mathrm{sp}$. NK-1 was isolated from the marine benthic region of Sagami bay in Japan [16]. This strain is a moderate halophilic bacterium that secretes a large amount of $\mathrm{P}(3 \mathrm{HB})$ depolymerse $\left(\mathrm{PhaZ}_{M s p}\right)$ into the growth medium in the presence of $\mathrm{P}(3 \mathrm{HB})$ or $(S)-3$-hydroxybutyric acid. The activity of $\mathrm{PhaZ}_{M s p}$ purified from culture supernatant was 
inhibited by diisopropyl fluorophosphate and phenylmethylsulfonyl fluoride, which were typical of serine hydrolase inhibitors. The N-terminal and internal amino acid sequences showed sequence homologies with those of Pseudomonas stutzeri $\mathrm{PhaZ}_{P s t}$. This paper reports the cloning and sequencing of the gene encoding $\operatorname{PhaZ}_{M s p}\left(p h a Z_{M \mathrm{sp}}\right)$. Furthermore, by using the recombinant expression of the $\mathrm{PhaZ}_{M s p}$ as glutathione $S$-transferase fusion proteins, the relation between the domain structure and its role were investigated.

\section{Materials and methods}

\subsection{Preparation of polymer sample}

The $\mathrm{P}(3 \mathrm{HB})$ granules were a gift from Monsanto (St. Louis, MO). To remove impurities, they were washed with distilled water, acetone and hexane. The purified granules were used as denatured $\mathrm{P}(3 \mathrm{HB})$ substrate $(\mathrm{dP}(3 \mathrm{HB}))$. $\mathrm{P}(3 \mathrm{HB})$ emulsion (eP(3HB)) was prepared according to the method of Horowitz and Sanders [17].

\subsection{Bacterial strains, plasmids, media and growth conditions}

Escherichia coli XL1-Blue $\mathrm{MRF}^{\prime}$ and E. coli DH5 $\alpha$ were used as host strains of the vectors. $E$. coli XLOLR was used as the host strain of in vivo excision. E. coli was grown at $37^{\circ} \mathrm{C}$ in a Luria-Bertani (LB) broth in the presence of ampicillin $(50 \mu \mathrm{g} / \mathrm{ml})$. Marinobacter sp. NK-1 (JCM 10458), which is a source of the genomic DNA and the $\mathrm{P}(3 \mathrm{HB})$ depolymerase, was grown at $30^{\circ} \mathrm{C}$. ZAP Express lambda phage (Stratagene) was used to construct Marinobacter sp. genomic sublibrary in E. coli XL1-Blue $\mathrm{MRF}^{\prime}$. pMSPSS that is a derivative of pUC18 contains $2.9 \mathrm{kbp}$ of Marinobacter sp. genomic DNA fragments digested by SmaI as an insert.

\subsection{Preparation of DNA probe}

A DNA probe for screening a $\mathrm{P}(3 \mathrm{HB})$ depolymerase gene of Marinobacter sp. was prepared by means of PCR using the total length of the phaZ $Z_{P s t}$ gene as the template [11]. The PCR product was purified by ethanol precipitation and labeled with DIG-High Prime kit (Boehringer Mannheim).

\subsection{DNA sequence analysis}

Nucleotide sequence was determined by the dideoxy-chain termination method with a Shimadzu DSQ 1000 sequencer (Shimadzu). The DNA and deduced amino acid sequences were analyzed using the sequence analysis program GENETYX (Software Development Co., Tokyo, Japan). Data base searches were performed using the program BLAST via the NCBI site.

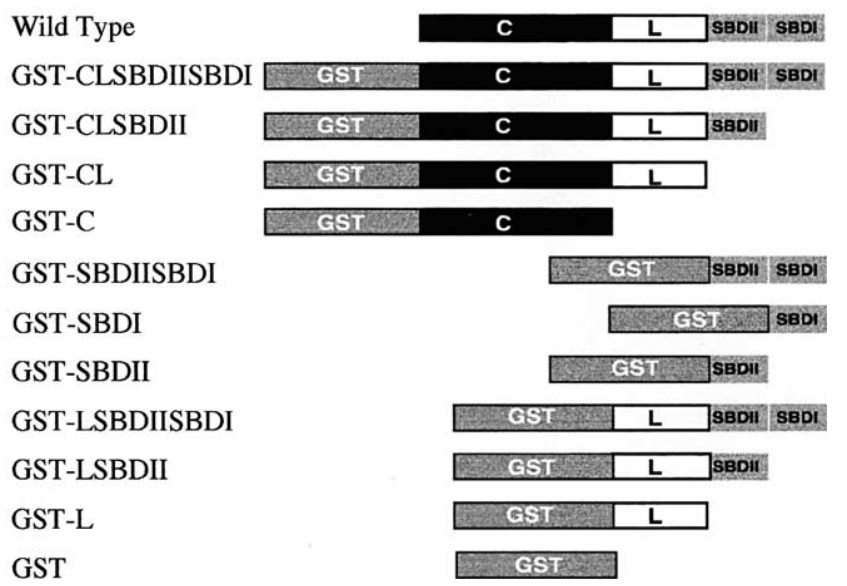

Fig. 1. Domain structures of wild-type $\mathrm{PhaZ}_{M s p}$ and GST fusion proteins. C, catalytic domain; L, linker domain; SBDI, substrate-binding domain I; SBDII, substrate-binding domain II; GST, glutathione $S$-transferase.

\subsection{Preparation of glutathione S-transferase fusion proteins}

DNA fragments encoding various types of glutathione $S$-transferase (GST) fusion proteins were obtained by polymerase chain reaction (PCR) amplification from plasmid pSSMSP carrying the $p h a Z_{M \text { sp }}$ gene. A BamHI restriction site (boldface) was introduced at the $5^{\prime}$-end of the oligonucleotide primer gst5 $\left(5^{\prime}\right.$-TCTGCTGGATCCGGGCAGACCGACT-3'), primer NLBam (5'-CGCTGGATCCCGGGATGGTCCTGAT- $\left.3^{\prime}\right)$ and primer gst3 (5'-GCTGGATCCGTGTATGACCCGAAAGCCC-3'), and primer gst1 (5'-TATTCCGGATCCGGCGTTCCGGATGAT-3') and an EcoRI restriction site (boldface) and stop codon (underlined) were introduced at the $5^{\prime}$-end of the oligonucleotide primer $\mathrm{CD}$ CEco (5'-AGGGAATTCTTAGTCATGAGCGGCGAAAAA-3'), primer gst6 (5'-GCCGTTGCGAATTCTTAGGTCTCTACAGGGGC- $3^{\prime}$ ), primer gst4 (5'-CGGGAATTCTTA GCAGGCAGAGGGTTCCTG- $\left.3^{\prime}\right)$ and primer gst 2 (5'-CGCCTGGAATTCTTATGGAC ACTGACCGGC- $\left.3^{\prime}\right)$. The PCR products including BamHI and EcoRI restriction sites prepared from the primer combinations gst $5+$ gst2, gst5 + gst4, gst5 + gst6, gst5 + CDCEco, NLBam + gst6, NLBam + gst 4 , NLBam + gst2, gst $3+$ gst 4, gst $1+$ gst 2 and gst $1+$ gst 2 were ligated into the BamHI and EcoRI digested pGEX-4T-1 (Pharmacia), yielding pCLSBDIISBDI, pCLSBDII, pCL, pC, pL, pLSBDIISBDI, pLSBDII, pSBDII, pSBDI and pSBDIISBDI, respectively. These plasmids encode the catalytic (C) + linker (L) domains + SBDII + SBDI, C $+\mathrm{L}+$ SBDII, C $+\mathrm{L}, \mathrm{C}$, $\mathrm{L}, \mathrm{L}+\mathrm{SBDII}+\mathrm{SBDI}, \mathrm{L}+$ SBDII, SBDII, SBDI and SBDII + SBDI with a GST (Fig. 1), respectively. The correct insertions of these genes were verified by DNA sequencing for both strands. To express the GST fusion protein, these chimeric plasmids were transformed into E. coli $\mathrm{DH} 5 \alpha$. The production and purification of GST 
Table 1

Specific activities of GST fusion proteins for three kinds of substrates

\begin{tabular}{|c|c|c|c|c|}
\hline \multirow[t]{2}{*}{ Fusion proteins } & \multirow[t]{2}{*}{ Molecular mass ${ }^{\mathrm{a}}$} & \multicolumn{3}{|c|}{ Specific activities for: } \\
\hline & & $\mathrm{PNPB}^{\mathrm{b}}(\mathrm{U} / \mathrm{mg})$ & $\mathrm{dP}(3 \mathrm{HB})^{\mathrm{c}}(\mathrm{U} / \mathrm{mg})$ & $\mathrm{eP}(3 \mathrm{HB})^{\mathrm{d}}(\mathrm{U} / \mathrm{mg})$ \\
\hline Wild-type (CLSBDIISBDI) & 58207 & $8.2 \pm 0.8$ & $16.7 \pm 1.0$ & $0.03 \pm 0.01$ \\
\hline GST-C & 61316 & $1.2 \pm 0.1$ & $0.60 \pm 0.1$ & $0.11 \pm 0.01$ \\
\hline GST-CL & 70638 & $4.4 \pm 0.4$ & $2.4 \pm 0.2$ & $0.18 \pm 0.01$ \\
\hline GST-CLSBDII & 77221 & $4.9 \pm 0.4$ & $5.0 \pm 0.5$ & $0.24 \pm 0.01$ \\
\hline GST-CLSBDIISBDI & 84553 & $3.8 \pm 0.4$ & $10.6 \pm 1.0$ & $0.14 \pm 0.01$ \\
\hline GST & 27897 & 0.0 & 0.0 & 0.0 \\
\hline
\end{tabular}

All assays were performed in triplicate.

a The molecular masses were calculated on the basis of amino acid sequences.

${ }^{\mathrm{b}} \mathrm{PNPB}, p$-nitrophenylbutyrate.

${ }^{c} \mathrm{dP}(3 \mathrm{HB})$, denatured poly(3-hydroxybutyrate).

d eP(3HB), poly(3-hydroxybutyrate) emulsified by Plysurf.

fusion proteins were performed as described previously [12].

\subsection{Binding assay}

$\mathrm{dP}(3 \mathrm{HB})$ and $\mathrm{eP}(3 \mathrm{HB})$ were used as the adsorbent. Four hundred micrograms of polymer substrates were suspended in $1.0 \mathrm{ml}$ of $50 \mathrm{mM}$ Tris- $\mathrm{HCl}$ buffer at $\mathrm{pH} 7.5$ and pre-incubated at $37^{\circ} \mathrm{C}$ for $5 \mathrm{~min}$. After preincubation, $10 \mu \mathrm{g}$ of fusion protein was added. The reaction mixture was incubated at $37^{\circ} \mathrm{C}$ for $10 \mathrm{~min}$ and then centrifuged in a TOMY rotor at $10,000 \times g$ for $1 \mathrm{~min}$. The amount of protein in the supernatant was determined by the Bradford method [18] or BCA method [19], using bovine serum albumin as the standard. The amount of enzyme bound to polymer granules was calculated from the values of soluble and added enzyme. The adsorption of GST-SBDI, GST-SBDII, and GST-SBDISBDII on the surface of $\mathrm{dP}(3 \mathrm{HB})$ at $37^{\circ} \mathrm{C}$ could be expressed by the Langmuir adsorption equation as described previously $[14,20]$. Based on the equation, the adsorption equilibrium constant $(K)$, which indicate the binding affinity between the protein and substrate, was determined. All assays were performed in triplicate. Experimental data with errors that represent the range of results obtained were shown in Table 2.

\subsection{Enzyme assay}

The activities of $\mathrm{P}(3 \mathrm{HB})$ depolymerase on $\mathrm{dP}(3 \mathrm{HB})$ and $\mathrm{eP}(3 \mathrm{HB})$ were assayed by measuring a decrease in turbidity at $650 \mathrm{~nm}$ and $37^{\circ} \mathrm{C}$. One unit of the enzyme was defined as the amount of enzyme required to decrease the value of $A_{650}$ by 1 per minute. The activity of $\mathrm{P}(3 \mathrm{HB})$ depolymerase on $p$-nitrophenyl butyrate (PNPB) was assayed by measuring the increase in absorption at $400 \mathrm{~nm}$ and $37^{\circ} \mathrm{C}$. One unit of the enzyme was defined as the amount of enzyme required to increase the value of $A_{400}$ by 1 per minute. All assays were performed in triplicate. Experimental data with errors that represent the range of results obtained were shown in Table 1.

\subsection{Nucleotide sequence accession number}

The DDBJ accession no. for $p h a Z_{M \text { sp }}$ is AB079799.

\section{Results}

\subsection{Cloning of the phaZ $Z_{M s p}$ gene from Marinobacter $s p$.}

Southern blots of genomic DNA of Marinobacter sp. digested with various restriction enzymes were hybridized with the DIG-labeled PCR product. An $8.0 \mathrm{kbp}$ $E c o R \mathrm{I}-E c o R \mathrm{I}$ fragment was hybridized to the probe. The fragment was ligated into the ZAP Express vector, and a genomic sublibrary was constructed in E. coli XL1-Blue $\mathrm{MRF}^{\prime}$. The positive recombinant clones were screened from the genomic sublibrary by plaque hybridization with the same probe. The positive recombinant clones were changed into $\mathrm{pBK}-\mathrm{CMV}$ plasmids by in vivo excision. Endonuclease mapping analysis revealed that all positive clones had the same $8.0 \mathrm{kbp} E c o R I-E c o R$ I fragment. Recombinant plasmid pSSMSP containing a $2.9 \mathrm{kbp} S m a \mathrm{I}-S m a \mathrm{I}$ fragment, which is a derivative of the $8.0 \mathrm{kbp} E c o R \mathrm{I}-E c o R \mathrm{I}$ fragment conferred the clear zone formation ability on the recombinant strains. However, the deletion derivatives of pSSMSP did not give the recombinant strains clear zone formation ability. As a result, the insertion sequence of pSSMSP contained a full-length $p h a Z_{M \text { sp }}$ structural gene. Therefore, sequencing analysis was performed for the SmaI-SmaI fragment. In addition, the gene products were confirmed using Western blotting. These results suggest that a $p h a Z_{M \text { sp }}$ promoter was located within the insert and that the $p h a Z_{M \text { sp }}$ gene product performed functional expression and secretion of $\mathrm{P}(3 \mathrm{HB})$ depolymerase in E. coli.

\subsection{Nucleotide sequence of the phaZ $Z_{M s p}$ gene}

The ORF of $p h a Z_{M s p}$ consists of $1737 \mathrm{bp}$ encoding a protein of 578 amino acids with a predicted molecular mass of $61,757 \mathrm{Da}$. The deduced amino acid sequence 


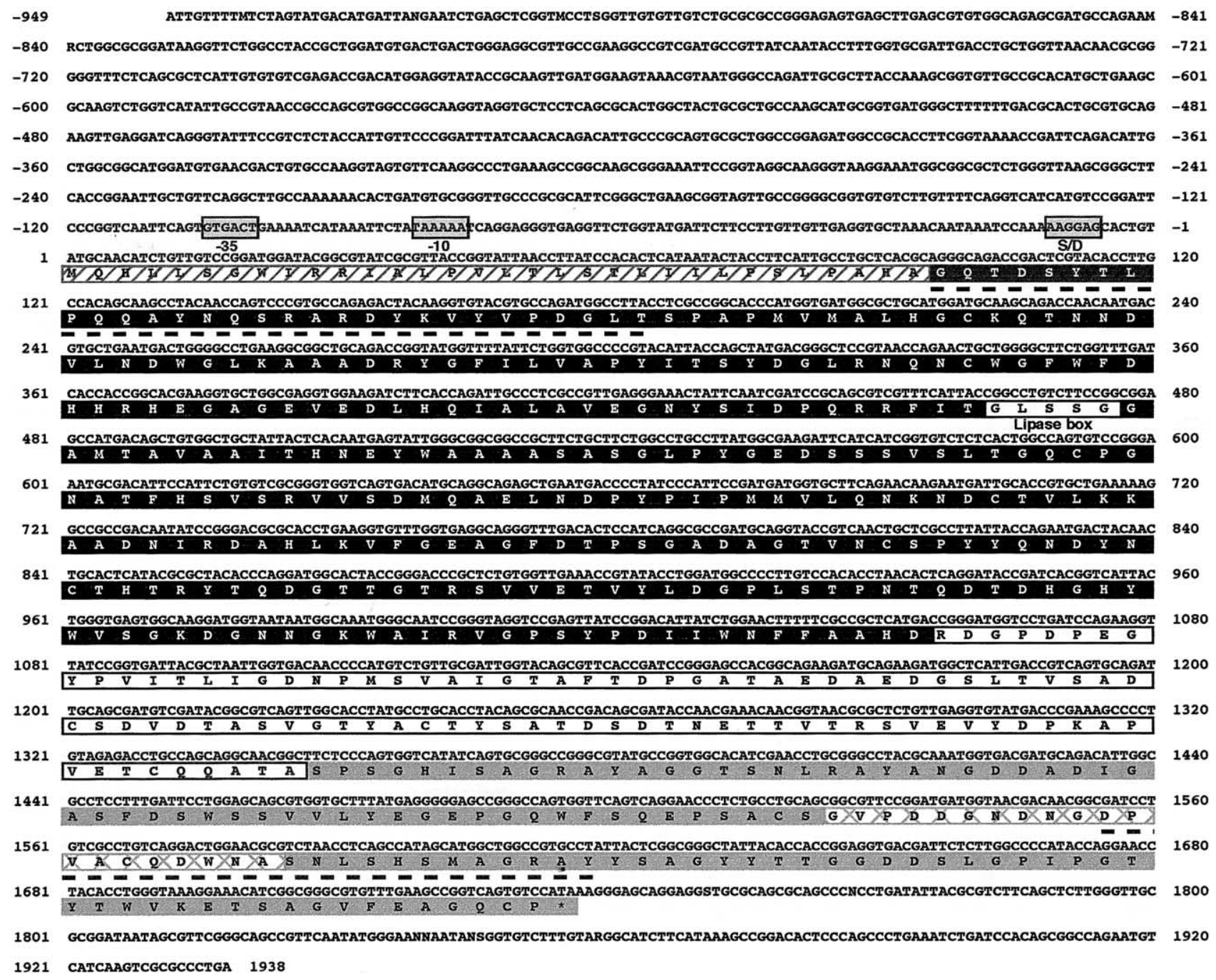

Fig. 2. Nucleotide sequence of the $p h a Z_{M \text { sp }}$ gene and deduced amino acid sequence of the gene product. A putative ribosome-binding (Shine-Dalgarno [S/D]) site and the -35 and -10 regions of a possible promoter sequence is boxed. Amino acid sequences confirmed by Edman degradation are broken underlined. A putative signal peptide is hatched boxed, a putative catalytic domain is closed boxed, a putative linker domain is open boxed, and putative SBDs are shaded.

of $\mathrm{PhaZ}_{M s p}$ showed a significant homology with those of $\mathrm{PhaZ}_{\text {Pst }}(65.9 \%)[11]$ and Pseudomonas sp. GM101 $\mathrm{PhaZ}_{P s p}(65.7 \%$, accession no. AF293347). The ORFX was located at $202 \mathrm{bp}$ upstream of the translational start of $p h a Z_{M \text { sp. }}$ The deduced amino acid sequence encoded by the ORFX showed significant sequence homology with those of $B$. subtilis ketoacyl reductase (accession no. NP_390259) and Haemophilus influenzae 3-ketoacyl-acyl carrier protein reductase (fabG) (NP_438325).

The N-terminal amino acid sequences determined for the mature $\mathrm{P}(3 \mathrm{HB})$ depolymerase $\left(\mathrm{PhaZ}_{M s p}\right)$ secreted by Marinobacter sp. (GQTDSYTLPQQAYNQSRARDYKVYVPDDLT) and its proteolytic fragments (DPVACQDXNASNLSHSMAGRXY) in our previous study [16] existed in the deduced amino acid sequence (Fig. 2). In addition, amino acid residues 33-63 of the deduced gene product were identical to the $\mathrm{N}$-terminal amino acid sequence determined for the mature $\mathrm{P}(3 \mathrm{HB})$ depolymerase secreted by
Marinobacter sp., suggesting that 32 amino acid polypeptide is a signal peptide.

\subsection{Domain structure of PhaZ $Z_{M s p}$}

Computer analysis revealed that the deduced protein contains four discrete domains: that is, catalytic, linker and two substrate-binding domain (SBD) (Fig. 2). The amino acid sequence of the catalytic domain (CD) showed sequence homology with those of $P$. stutzeri PhaZ $_{P s t}$ (level of identity, 71.9\%) [11], Pseudomonas sp. $\mathrm{PhaZ}_{P s p}(71.7 \%$, accession no. AAG00611), Streptomyces hygroscopicus $\mathrm{P}(3 \mathrm{HB})$ depolymerase (34.9\%) [21] and P. lemoignei PhaZ5 Ple (26.5\%) [10]. The CD contained conserved amino acids of the catalytic triad $\mathrm{Ser}_{157}$, Asp 234 and $\mathrm{His}_{283}$ together with the surrounding conserved sequences, which functions as an active center in many known serine hydrolases $[9,22]$. The $\operatorname{Ser}_{157}$ was also one of the amino acid residues 
comprising a lipase box-like sequence ( $\mathrm{GxSxG})$. Together with the previous results of an inhibition test [16], these suggest that $\mathrm{PhaZ}_{M s p}$ belongs to a serine hydrolase class. The amino acid sequence of linker domain (LD) exhibited significant homology with cadherin-like type linker, which was observed in the linker region of some $\mathrm{P}(3 \mathrm{HB})$ depolymerases or chitinases, such as those of $\mathrm{PhaZ}_{P s t}$ (67.5\%), the reiterated region of Vibrio harveyi Chitinase A (48.2, 40.0\%) [23] and Clostridium paraputrificum Chitinase B $(43.0,33.7 \%)$ [24]. At the C-terminal region of the deduced protein, two SBDs existed. These regions separated by a spacing of 20 amino acids were designated to SBDI (amino acids 529-578) and SBDII (amino acids 450-508), respectively. These SBDs had the conserved motif sequence observed in all SBDs: that is, sxxxHxxAGRa.

\subsection{Functional analyses of $P h a Z_{M s p}$}

Ten kinds of $\mathrm{PhaZ}_{M s p}$ derivatives were constructed as GST fusion proteins to investigate the relation between domain structure and function (Fig. 1). Molecular masses of the fusion proteins purified from E. coli were consistent with those calculated based on the amino acid sequences (data not shown).

Table 1 lists the specific activities of those fusion proteins for three types of substrates, together with the calculated molecular mass of wild-type and fusion proteins. Four proteins containing the $\mathrm{CD}$, except for GST-C, exhibited substrate specificities similar to one another for PNPB, which is a water-soluble substrate. This suggests that the water-soluble substrate was degraded only by the function of the $\mathrm{CD}$, independent of the presence of the SBDs. However, GST-C lacking LD showed lower activity for PNPB compared to the other proteins. On the other hand, three enzymes with all domains of CD, LD and SBD hydrolyzed $\mathrm{dP}(3 \mathrm{HB}) 2-7$ times faster than GST-CL with the CD lacking SBD. Furthermore, GST-C had a four times lower activity for $\mathrm{dP}(3 \mathrm{HB})$ than GST-CL. Five proteins with the CD showed substrate specificities similar to one another for $\mathrm{eP}(3 \mathrm{HB})$, which is an amorphous and water-insoluble substrate, independent of the presence of the SBD, indicating that $\mathrm{eP}(3 \mathrm{HB})$ was hydrolyzed only by the function of the $\mathrm{CD}$.

Table 2 lists the binding specificity of six fusion proteins and GST against $\mathrm{dP}(3 \mathrm{HB})$ and $\mathrm{eP}(3 \mathrm{HB})$. Five GST fusion proteins containing SBD were bound to $\mathrm{AP}(3 \mathrm{HB})$ with the crystalline part. However, the proteins without SBD, that is, GST and GST-L, showed no binding activities to $\mathrm{dP}(3 \mathrm{HB})$. All proteins used in this study were not bound to $\mathrm{eP}(3 \mathrm{HB})$, which is amorphous fluid.

Kinetic analysis revealed that the adsorption equilibrium constant $(K)$ of GST-SDBI, GST-SBDII and GST-SBDIISBDI to $\mathrm{dP}(3 \mathrm{HB})$ were determined as $0.47 \pm 0.1$, $0.28 \pm 0.1$ and $0.57 \pm 0.1 \mathrm{ml} / \mu \mathrm{g}$, respectively.
Table 2

Binding specificities of fusion proteins

\begin{tabular}{llll}
\hline Fusion proteins & $\begin{array}{l}\text { Molecular } \\
\text { mass }^{\mathrm{a}}\end{array}$ & \multicolumn{2}{l}{ Amount of protein bound to ${ }^{\mathrm{b}}:$} \\
\cline { 3 - 4 } & & $\mathrm{dP}(3 \mathrm{HB})^{\mathrm{c}}(\mu \mathrm{g})$ & $\begin{array}{l}\mathrm{eP}(3 \mathrm{HB})^{\mathrm{d}} \\
(\mu \mathrm{g})\end{array}$ \\
\hline GST-L & 35650 & 0.0 & 0.0 \\
GST-LSBDII & 42233 & $1.41 \pm 0.1$ & 0.0 \\
GST-LSBDIISBDI & 49565 & $1.46 \pm 0.1$ & 0.0 \\
GST-SBDII & 34011 & $1.45 \pm 0.1$ & 0.0 \\
GST-SBDI & 33574 & $1.86 \pm 0.1$ & 0.0 \\
GST-SBDIISBDI & 41344 & $1.70 \pm 0.1$ & 0.0 \\
GST & 27897 & 0.0 & 0.0 \\
\hline
\end{tabular}

n.d.: not determined. All assays were performed in triplicate.

a The molecular masses were calculated on the basis of amino acid sequences.

b $10 \mu \mathrm{g}$ of fusion proteins were used in each assay.

${ }^{c} \mathrm{dP}(3 \mathrm{HB})$, denatured $\mathrm{P}(3 \mathrm{HB})$.

$\mathrm{d}$ eP(3HB), P(3HB) emulsified by Plysurf.

\section{Discussion}

This paper describes the cloning and expression of PhaZ $Z_{M s p}$ and the functional analysis of the domain using GST fusion proteins. The $\mathrm{P}(3 \mathrm{HB})$ depolymerase gene $\left(p h a Z_{M \text { sp }}\right)$ encoded a polypeptide $\left(\mathrm{PhaZ}_{M s p}\right)$ composed of 578 amino acids. PhaZ $Z_{M s p}$ adopted three functional domains structure (Fig. 2). The N-terminal 32 amino acid residues showed typical characteristics of signal peptides, which are composed of a positively charged region $\left(\mathrm{M}_{1}\right.$ to $\left.\mathrm{R}_{11}\right)$, a hydrophobic region $\left(\mathrm{I}_{12}\right.$ to $\left.\mathrm{P}_{29}\right)$ and a signal sequence cleavage site $\left(\mathrm{A}_{30} \mathrm{H}_{31} \mathrm{~A}_{32} \downarrow\right)$. The $\mathrm{N}$-terminal amino acid sequence of the cloned enzyme was identical to that of the mature enzyme produced by Marinobacter sp., indicating that the signal peptide functions in E. coli.

At the $\mathrm{C}$ terminus of $\mathrm{PhaZ}_{M s p}$ there are two SBDs that show sequence homology to other bacterial SBDs. A binding test revealed that the binding affinities $(K=0.37 \pm$ $0.09 \mathrm{ml} / \mu \mathrm{g})$ to $\mathrm{dP}(3 \mathrm{HB})$ of two SBDs are much smaller than those $(1.0 \pm 0.1 \mathrm{ml} / \mu \mathrm{g})$ [14] of other $\mathrm{P}(3 \mathrm{HB})$ depolymerases that have only one SBD. On the other hand, the $K$ values of SBDs of $\mathrm{PhaZ}_{M s p}$ are similar to those of SBDs of $\mathrm{PhaZ}_{P s t}$ which has two SBDs [11]. Thus, $\mathrm{PhaZ}_{M s p}$ has two SBDs to compensate for the weak binding affinity of each SBD.

Previous studies have shown that several bacterial SBDs were specifically bound to solid polyester granules such as $\mathrm{P}(3 \mathrm{HB}), \mathrm{P}(3 \mathrm{HP})$, and PLA [11,14]. These results imply that there are some specific interactions between conserved amino acid residues in the SBD and common chemical structure existed in the polyester, such as carbonyl group [14]. On the other hand, whole molecule of $\mathrm{PhaZ}_{R p i}$ showed little binding activity for amorphous $\mathrm{P}(3 \mathrm{HB})$, suggesting that the SBD may need the rigidity for adsorbent in addition to the distinctively chemical structure in the polyesters $[25,26]$. In this study, to make clear the contribution of $\mathrm{PhaZ}_{M s p}$ SBDs in the enzymatic hydrolysis of $\mathrm{P}(3 \mathrm{HB})$, the binding and hy- 
drolysis tests using several fusion proteins and two types of $\mathrm{P}(3 \mathrm{HB})$ substrates with different states, that is, $\mathrm{dP}(3 \mathrm{HB})$ and $\mathrm{eP}(3 \mathrm{HB})$ were performed. As a result, both SBDI and SBDII of $\mathrm{PhaZ}_{M s p}$ did not recognize eP(3HB) but $\mathrm{dP}(3 \mathrm{HB})$ as adsorbent (Table 2), although the chemical structure of $\mathrm{eP}(3 \mathrm{HB})$ is identical to that of $\mathrm{dP}(3 \mathrm{HB})$. This appears to be caused by the difference in the state of substrates. Accordingly, it is assumed that the rigid part in the adsorbent is absolutely required for the binding to the substrate of the SBDs, whereas the presence of the distinctively chemical structure in the polyester (e.g. carbonyl group) is a not sufficient but necessary condition due to the substrate recognition of SBDs. In addition, three enzymes with both CD and SBD showed higher specific activities for $\mathrm{dP}(3 \mathrm{HB})$ compared to other enzymes without the SBD (Table 1). On the other hand, these enzymes showed comparatively similar specific activities for $\mathrm{eP}(3 \mathrm{HB})$ independent of the presence of SBDs (Table 1), indicating that the SBDs have no influence on the hydrolytic activities of them for eP(3HB). Taken together, these results indicate that $\mathrm{PhaZ}_{M s p}$ is concentrated on the $\mathrm{dP}(3 \mathrm{HB})$ by the SBDs, which can be bound only to a solid substrate, resulting in the SBDs contributing to an enhancement of the hydrolysis of the solid substrate by the CD.

The function of the LD of $\mathrm{P}(3 \mathrm{HB})$ depolymerases has not been well understood. Saito and coworkers have proposed that the fibronectin type III LD of $\mathrm{PhaZ}_{R p i}$ could convert the crystalline part of $\mathrm{dP}(3 \mathrm{HB})$ surface into the amorphous [13]. In our previous study [11], we reported that the cadherine-type $\mathrm{LD}$ of $\mathrm{PhaZ}_{P s t}$ may play a structural role in the maintaining an optimal distance between the $\mathrm{CD}$ and SBDs to make the CD work effectively. In this study, it was found that the removal of the cadherin-type LD from PhaZ $Z_{M s p}$ caused decrease in the activity not only to solid substrate but also to water-soluble substrate, indicating that the LD is involved in an enhancement of the activities. Such an enhancement effect by the LD is different from the above-mentioned effect by the SBDs, that is, the concentration effect to the substrate surface, since the LD did not show binding activity to $\mathrm{dP}(3 \mathrm{HB})$ and the enhancement by the LD is effective for both solid and water-soluble substrates. These suggest that the cadherine-type LD of $\mathrm{PhaZ}_{M s p}$ may be engaged in the maintaining the catalytically active conformation of the CD.

\section{Conclusions}

We cloned a DNA fragment carrying the gene $\left(p h a Z_{M \mathrm{sp}}\right)$ encoding $\mathrm{P}(3 \mathrm{HB})$ depolymerase from Marinobacter $\mathrm{sp}$. The Marinobacter sp. $\mathrm{P}(3 \mathrm{HB})$ depolymerase gene is composed of $1734 \mathrm{bp}$ and encodes 578 amino acids. The deduced protein $\left(\mathrm{PhaZ}_{M s p}\right)$ was composed of three kinds of discrete domains, that is, the $\mathrm{CD}$ containing the catalytic machinery, 2 SBDs to concentrate the enzyme molecule onto the surface of $\mathrm{P}(3 \mathrm{HB})$, and cadherine-type LD to link other 2 domains. By using recombinant expressions of each domain as GST fusion proteins, the functions of each domain were investigated. It was found that the SBDs need the rigid part to bind to the substrate, while it does not recognize an $\mathrm{eP}(3 \mathrm{HB})$ that is a fluid substrate as adsorbent. It was concluded that SBDs contribute to an enhancement of the hydrolysis of the solid substrate by the CD. In addition, the cadherine-type LD of $\mathrm{PhaZ}_{M s p}$ may be engaged in the maintaining the catalytically active conformation of the CD.

\section{Acknowledgements}

This study was partly supported by a grant-in-aid for scientific research on the priority area, "Sustainable Biodegradable Plastics", no. 11217202 from the Ministry of Education, Science, Sports and Culture (Japan), and by Solution Oriented Research for Science and Technology (SORST) of the Japan Science and Technology Corporation (JST).

\section{References}

[1] Anderson AJ, Dawes EA. Microbiol Rev 1990;54:450-77.

[2] Steinbüchel A. Polyhydroxyalkanoic acids. In: Byrom D, editor. Biomaterials. London, England: Macmillan; 1991. p. 123-213.

[3] Kawaguchi Y, Doi Y. FEMS Microbiol Lett 1990;70:151-6.

[4] Doi Y. Microorganisms and poly(3-hydroxyalkanoates). Microbial polyesters. New York, NY: VCH Publishers; 1990. p. 33-62.

[5] Luzier WD. Proc Natl Acad Sci USA 1992;89:839-42.

[6] Mergaert J, Weeb A, Anderson C, Wouters A, Swings J. Can J Microbiol 1995;41(Suppl 1):154-9.

[7] Janssen PH, Harfoot CG. Arch Microbiol 1990;154:253-9.

[8] Mukai K, Yamada K, Doi Y. Polym Degrad Stab 1993;41:85-91.

[9] Jendrossek D, Schirmer A, Schlegel HG. Appl Microbiol Biotechnol 1996;46:451-63.

[10] Jendrossek D, Frisse A, Behrends A, Andermann M, Kratzin HD, Stanislawski T, et al. J Bacteriol 1995;177:596-607.

[11] Ohura T, Kasuya K, Doi Y. Appl Environ Microbiol 1999;65:189-97.

[12] Kasuya K, Inoue Y, Tanaka T, Akehata T, Iwata T, Fukui T, et al. Appl Environ Microbiol 1997;63:4844-52.

[13] Nojiri M, Saito T. J Bacteriol 1997;179:6965-70.

[14] Kasuya K, Ohura T, Masuda K, Doi Y. Int J Biol Macromol 1999;24:329-36.

[15] Handrick R, Reinhardt S, Focarete ML, Scandola M, Adamus G, Kowalczuk M, et al. J Biol Chem 2001;276:36215-24.

[16] Kasuya K, Mitomo H, Nakahara M, Akiba A, Kudo T, Doi Y. Biomacromolecules 2000;1:194-201.

[17] Horowitz DM, Sanders JKM. J Am Chem Soc 1994;116:2695-702.

[18] Bradford MM. Anal Biochem 1976;72:248-54.

[19] Smith PK, Krohn RI, Hermanson GT, Mallia AK, Gartner FH, Provenzano MD, et al. Anal Biochem 1985;150:76-85.

[20] Kasuya K, Inoue Y, Doi Y. Int J Biol Macromol 1996;19:35-40.

[21] Wu K, Chung L, Revill WP, Katz L, Reeves CD. Gene 2000;251:8190.

[22] Brady L, Brzozowski AM, Derewenda ZS, Dodson E, Dodson G, Tolley S, et al. Nature 1990;343:767-77.

[23] Svitil AL, Kirchman DL. Microbiology 1998;144:1299-308.

[24] Morimoto K, Karita S, Kimura T, Sakka K, Ohmiya K. J Bacteriol 1997;179:7306-14.

[25] He Y, Shai X, Kasuya K, Doi Y, Inoue Y. Biomacromolecules 2001;2:1045-51.

[26] Abe H, Doi Y. Macromolecules 1996;29:8683-6. 